\title{
Genetic variability and trait association under thrips (Megalurothrips sjostedti Trybom) infestation in cowpea (Vigna unguiculata [L.] Walp.)
}

\author{
Johnson Oluwaseyi Toyinbo (D) Christian Fatokun • Ousmane Boukar • \\ Morakinyo Abiodun Bamidele Fakorede
}

Received: 28 January 2021 / Accepted: 5 May 2021/Published online: 14 May 2021

(C) The Author(s) 2021

\begin{abstract}
Flower bud thrips is one of the most destructive insect pests of cowpea in sub-Saharan Africa. Information on genetic variability among cowpea germplasm and interrelationships among traits under thrips infestation would facilitate the development of resistant varieties. The objectives of the study were to assess genetic variability for thrips resistance, estimate heritability of yield and other traits and investigate inter-trait relationships under thrips infestation. One hundred and fifty-six cowpea lines, including one resistant and one susceptible check, were screened for resistance under natural infestation at two locations in Nigeria, in 2016. Test lines were scored for thrips damage weekly for three consecutive weeks, after removal of spreader plants, to obtain damage scores (DS) 1, 2 and 3 while data were
\end{abstract}

Supplementary Information The online version contains supplementary material available at https://doi.org/10.1007/ s10681-021-02849-1.

J. O. Toyinbo $(\bowtie) \cdot$ M. A. B. Fakorede

Department of Crop Production and Protection, Obafemi Awolowo University, Ile-Ife, Nigeria

e-mail: johnsontoyinbo@gmail.com

\section{J. O. Toyinbo · C. Fatokun}

International Institute of Tropical Agriculture, PMB 5320,

Oyo Road, Ibadan, Nigeria

O. Boukar

International Institute of Tropical Agriculture, Kano, Nigeria collected on agronomic traits. The data were subjected to analysis of variance from which genetic components of the phenotypic variance were computed. Interrelationships among traits were determined using phenotypic and genotypic correlation, and sequential path analyses. Significant variability was observed among test lines. Lines TVu 6824 and TVNu 1307 were identified as possessing thrips resistance. DS3 had significant genetic and phenotypic correlations with DS1, DS2 and yield-related traits. Number of pods per peduncle, number of peduncles per plant and DS3 were identified as first-order traits. Heritability estimates ranged from 0.55 to 0.73 . Genetic variability among the lines suggests the possibility of genetic control of thrips while number of pods per peduncle, number of peduncles per plant and DS3 would serve as useful selection criteria for thrips resistance.

Keywords Cowpea - Genetic variability - Thrips . Heritability $\cdot$ Path analysis

\section{Introduction}

Cowpea [Vigna unguiculata (L.) Walp.] is an important food legume crop that provides quality nourishment for both humans and livestock, particularly in sub-Saharan Africa (SSA). The interactive effect of high lysine and tryptophan from cowpea, as well as high cysteine and methionine along with energy from 
cereals enhances the meal protein quality and nutritional balance of cereal-based diets of both rural and urban population of the region (Singh et al. 2002). Cowpea plant biomass is a source of nutritious fodder for ruminants in the Savanna of West and Central Africa (Boukar et al. 2016). In West and Central Africa, an estimated 200 million people consume cowpea daily (Kormawa et al. 2002). Therefore, trading fresh cowpea produce, processed food and snacks provides rural and urban women with opportunity for earning cash income.

Cowpea production is faced with several limitations. Insect pests, plant diseases, parasitic flowering plants and moisture stress are major yield limiting factors of cowpea (Terao et al. 1997). Average grain yield of the crop in West and Central Africa is about $0.45 \mathrm{t} / \mathrm{ha}$ (Haruna and Usman 2013) even though there are lines which, with good management, can produce yield above $2.0 \mathrm{t} / \mathrm{ha}$ (Singh et al. 1997). Insect pests are largely responsible for this substantial grain yield deficit. Every stage in the life cycle of cowpea has at least a major insect pest that can cause severe damage and reduce yield (Fatokun 2002). Several insect pests attack the crop throughout its growth stages, from seedling to maturity and even in storage causing tremendous economic losses. In West Africa, the first major and most destructive insect pest of cowpea at reproductive stage is the flower bud thrips (Megalurothrips sjostedti Trybom) (Omo-Ikerodah et al. 2009). Yield reduction attributable to thrips damage ranges from 20 to $80 \%$ but severe infestation may lead to total crop failure (Singh and Allen 1980). Thrips feed on cells of flower buds and flowers resulting in browning of stipules, and distortion and abscission of flowers (Jackai and Daoust 1986; Oladejo et al. 2017), thereby inhibiting pod formation. Apart from causing direct damage on cowpea, thrips are vectors for a number of pathogens which they transmit mechanically from one plant to another. Nault (1997) reported that thrips serve as vectors for transmitting more than 20 plant-infecting viruses.

Use of synthetic insecticides is one of the most widely adopted methods of control of thrips. However, insecticide resistance detected in thrips population has rendered chemical treatments ineffective (Morse and Hoddle 2006). Also, the associated human health and environmental hazards make this form of control less desirable. Host plant resistance, which is the most promising alternative has been a major goal of most cowpea breeding programs in sub-Saharan Africa (Okonya and Maass 2014). In view of its economic, food security and nutrition security importance, concerted efforts are required towards developing thrips resistant varieties which SSA farmers can grow successfully with limited need for insect control measures.

Improvement of cowpea for resistance to flower thrips requires information on the extent of genetic variability that exists among available cowpea germplasm while adequate knowledge of interrelationships among traits under thrips infestation is important for effective selection. Several independent field and screenhouse evaluations have been conducted to identify thrips resistant cowpea lines. Sanzi, a landrace from Ghana, and TVu 1509, a line developed at Obafemi Awolowo University, Ile-Ife, Nigeria were reported as possessing some level of resistance to flower bud thrips (Omo-Ikerodah et al. 2009). Similarly, lines NGT 65B, TVu 2723, CIPEA 82672 and Suvita 2 have been found resistant (Oladejo 2015; Doumbia et al. 2019). Higher levels of resistance are desirable as low levels succumb to the pest when infestation is severe (Omo-Ikerodah et al. 2009). Also, if resistance genes are many and non-allelic, they could be assembled in elite varieties, facilitated by newly developed cowpea genomic tools, to achieve more durable resistance, a process referred to as gene pyramiding (Raj and Sanghamitra 2010). The objectives of the present study were to assess genetic variability for resistance to thrips in cowpea, identify resistant lines, estimate heritability of yield and its components, and investigate relationships among traits under thrips-imposed stress.

\section{Materials and methods}

\section{Genetic materials}

One hundred and forty-six (comprising of 109 cultivated lines, 35 lines of wild relatives and 2 checks) of 154 cowpea lines obtained from the IITA-Genetic Resource Centre were successfully screened for thrips resistance at the IITA experimental field, Fasola, $\left(7^{\circ}\right.$ $51^{\prime} \mathrm{N}, 3^{\circ} 56^{\prime} \mathrm{E}, 258 \mathrm{~m}$ altitude), and Obafemi Awolowo University Teaching and Research Farm (OAUT\&RF), Ile-Ife $\left(7^{\circ} 28^{\prime} \mathrm{N}, 4^{\circ} 33^{\prime} \mathrm{E}, 244 \mathrm{~m}\right.$ altitude), Nigeria in 2016. Fasola is located between 
Oyo and Iseyin in the derived savanna agro-ecology while Ile-Ife is in the Forest-savanna transition zone. The screening experiment was laid using randomized incomplete block design with three replicates. Each replicate contained 11 blocks and each block had 14 entries, planted into a $2 \mathrm{~m}$ single-row plot at a between-row spacing of $75 \mathrm{~cm}$ and within-row spacing of $20 \mathrm{~cm}$. Vita 7 (susceptible line) was first planted as spreader around experimental plot to attract and build up thrips population and test lines were planted two weeks after. Plants of the spreader line were uprooted at 35 days after planting and laid uniformly among test lines to which the insects migrated. Starting one week after uprooting of the spreader line and based on known symptoms, test lines were scored for thrips damage for three consecutive weeks to obtain damage scores 1, 2 and 3. Scoring was done on a scale of 1-9 where 1 = highly resistant/low susceptibility with slight or no visible damage and $9=$ highly susceptible with severe damage (Jackai and Singh 1988). It should be noted that the symptoms of damages caused to cowpea plants by flower bud thrips are unique and easily distinguishable while scoring. Data were also collected on number of pods per plant, number of peduncles per plant, and number of pods per peduncle. In the present study, number of pods was considered as yield due to the confounding effects caused by other insect pests as no form of protection against flower thrips or any other insect pest was given, even though a complex of insect pests infested the plants. Weeds were controlled manually.

\section{Data analysis}

Thrips damage scores were log-transformed and, along with the agronomic data were subjected to analysis of variance (ANOVA) using Statistical Analysis System software, version 9.3 (SAS Institute 2001). The statistical model for the ANOVA was:

$$
\mathrm{Y}_{\mathrm{ijkl}}=\mu+\mathrm{E}_{\mathrm{i}}+\mathrm{R}_{\mathrm{j}(\mathrm{i})}+\mathrm{B}_{\mathrm{k}(\mathrm{ij})}+\mathrm{G}_{\mathrm{l}}+(\mathrm{GE})_{\mathrm{il}}+€_{\mathrm{ijk} \mathrm{l}}
$$

In this model, $\mathrm{Y}_{\mathrm{ijkl}}$ is the observed measurement for the lth genotype in the kth block of the jth replicate, within the ith environment; $\mu$ is the grand mean; $E_{i}$ is the main effect of the environment; $R_{j(i)}$ is the effect of replicate nested within Environment; $B_{k(i j)}$ is the effect of block nested within replicate $\mathrm{j}$ by environment $\mathrm{i} ; \mathrm{G}_{1}$ is the effect of genotype; $(\mathrm{GE})_{\mathrm{il}}$ is the genotype by environment interaction effect, and $€_{\mathrm{ijkl}}$ is the error term. In this model, all factors were considered as random.

Genetic variance was estimated by equating the observed mean squares in the ANOVA to their expectations and computing for the desired component.

Genetic variance, $\sigma^{2} g=\frac{\mathrm{M}_{3}-\mathrm{M}_{2}}{\mathrm{re}}$

where $\mathrm{M}_{3}, \mathrm{M}_{2}, \mathrm{r}$ and e refer to genotype mean squares, genotype $\times$ environment interaction mean squares, replicates within environment and number of environments, respectively.

Broad-sense heritability was computed as the ratio of the genetic variance to the phenotypic variance on a progeny-mean basis, along with the standard error as follows:

Broad-sense heritability, $\mathrm{h}_{b}^{2}=\frac{\mathrm{s}_{g}^{2}}{\mathrm{~s}_{g}^{2}+\frac{\mathrm{s}_{g e}^{2}}{\mathrm{e}}+\frac{\mathrm{s}_{e}^{2}}{\mathrm{re}}}$

where $r$ is number of replicates per environment; $e$ is number of environments; $\mathrm{s}_{\mathrm{g}}^{2}$ represents the components of variance estimate due to the test lines; $\mathrm{s}^{2}$ ge is the component of variance due to test lines $x$ environment interactions; and $\mathrm{s}_{\mathrm{e}}^{2}$ is the estimate of experimental error variance.

The test lines were subjected to cluster analysis using the Ward's minimum variance method (Ward 1963) available in the CLUSTER procedure of SAS statistical package (SAS Institute 2001) while genetic and phenotypic correlation coefficients were computed using SAS software, version 9.3 (SAS Institute 2001). Stepwise-multiple regression and sequential path analyses were performed to investigate associations among thrips damage scores and other traits using the SAS software, version 9.3 (SAS Institute 2001).

The sequential stepwise multiple regression analysis was performed to categorize the traits into first-, second- and third-order on the basis of their effects on yield. Firstly, yield was regressed on all other traits besides yield and the traits with significant effects $(P \leq 0.05)$ were regarded as first-order traits. Secondorder traits were identified by regressing each of the first-order traits on the remaining traits. This procedure was repeated to identify those in the third order. Path-coefficients were the standardized partial 
regression coefficients obtained from the regression analysis (Mohammadi et al. 2003). The path coefficients were tested for significance using the t-test at 0.05 level of probability and only the traits with significant path co-efficients were retained.

\section{Results}

The combined ANOVA over environments revealed significant variations $(P<0.01)$ among genotypes $(\mathrm{G})$ for all measured traits (Table 1) while variation between environments (E) was also significant $(P<0.01)$ for all traits except damage score 1 and number of peduncles per plant. Genotype $x$ environment interaction (GEI) effect was significant for all traits except thrips damage score 1 and number of pods per peduncle. Two lines, TVNu 1307 and TVu 6824 showed high resistance to thrips (Supplementary 1). Wide ranges were observed among the test lines for all traits under study (Table 2). For example, damage score 3 ranged from 2.00 to 9.00 with a mean of 6.99 , indicating that many more of the test lines were susceptible. Number of pods per plant ranged from 0.00 to 3.20 with a mean of 0.81 . Broad-sense heritability estimates varied between 0.55 for number of pods per plant and 0.73 for number of pods per peduncle (Table 3).

Cluster analysis at average distance between 15 and 20 units classified the test lines into five groups under flower bud thrips infestation (Fig. 1). The first group comprised of only one line, TVNu 1307. The second contained 16 lines, the third group 22, the fourth 89
Table 2 Ranges, means and standard errors ( \pm S.E) of damage scores and some agronomic traits of 146 cowpea lines evaluated under natural flower bud thrips infestation at Fasola and Ile-Ife, 2016

\begin{tabular}{lccr}
\hline Trait & Minimum & Maximum & Mean \pm S.E. \\
\hline DS 1 & 1.50 & 5.50 & $3.05 \pm 0.04$ \\
DS 2 & 1.50 & 6.00 & $4.49 \pm 0.05$ \\
DS 3 & 2.00 & 9.00 & $6.99 \pm 0.09$ \\
Pods/Plt & 0.00 & 16.33 & $0.81 \pm 0.09$ \\
Peds/Plt & 12.50 & 42.00 & $21.56 \pm 0.49$ \\
Pods/Ped & 0.00 & 1.19 & $0.10 \pm 0.01$ \\
\hline
\end{tabular}

DS 1 damage score 1, DS 2 damage score 2, DS 3 damage score 3, Pods/Plt number of pods/plant, Peds/Plt number of pods/ peduncle, Pods/Ped number of peduncles/plant

Table 3 Estimates of broad-sense heritability ( \pm SE) of damage scores and agronomic traits in cowpea lines evaluated under natural flower bud thrips infestation at Fasola and Ile-Ife, 2016

\begin{tabular}{ll}
\hline Trait & $\mathrm{H}_{\mathrm{b}}{ }^{2}$ \\
\hline DS 1 & $0.70 \pm 0.06^{* *}$ \\
DS 2 & $0.70 \pm 0.14^{* *}$ \\
DS 3 & $0.68 \pm 0.17 * *$ \\
Pods/Plt & $0.55 \pm 0.12^{* *}$ \\
Peds/Plt & $0.69 \pm 0.18^{* *}$ \\
Pods/Ped & $0.73 \pm 0.01 * *$ \\
\hline
\end{tabular}

DS 1 damage score 1, DS 2 damage score 2, DS 3 damage score 3, Pods/Plt number of pods/plant, Peds/Plt number of pods/ peduncle, Pods/Ped number of peduncles/plant

**Significantly different from zero at 0.01 level of probability

Table 1 Analysis of variance for flower bud thrips damage scores and some agronomic traits of 146 cowpea lines evaluated under natural infestation at Fasola and Ile-Ife in 2016

\begin{tabular}{llllcccc}
\hline Source of variation & DF & DS 1 & DS 2 & DS 3 & Pods/Plt & Ped/Plt & Pods/Ped \\
\hline Environment (E) & 1 & 3.04 & $23.14^{* *}$ & $54.13^{* *}$ & $2993.15^{* *}$ & 284.22 & $5.01^{* *}$ \\
Rep/E & 4 & $8.97^{* *}$ & $36.50^{* *}$ & 4.52 & 161.31 & $13,395.8^{* *}$ & $0.52^{* *}$ \\
Blk(Rep * E) & 60 & $2.61^{*}$ & $2.96^{* *}$ & 3.41 & 31.82 & $999.01^{* *}$ & 0.08 \\
Genotype (G) & 145 & $3.76^{* *}$ & $7.94 * *$ & $12.72^{* *}$ & $162.61^{* *}$ & $1370.81^{* *}$ & $0.30^{* *}$ \\
G x E & 145 & 1.13 & $2.42^{* *}$ & $4.29^{*}$ & $72.45^{* *}$ & $423.20^{*}$ & 0.08 \\
Error & 582 & 1.13 & 1.02 & 3.40 & 39.62 & 334.08 & 0.07 \\
\hline
\end{tabular}

DS 1 damage score 1, DS 2 damage score 2, DS 3 damage score 3, Pods/Plt number of pods/plant, Peds/Plt number of peduncles/plant, Pods/Ped number of pods/peduncle

*, **Indicate significant F-test at 0.05 and 0.01 level of probability, respectively 


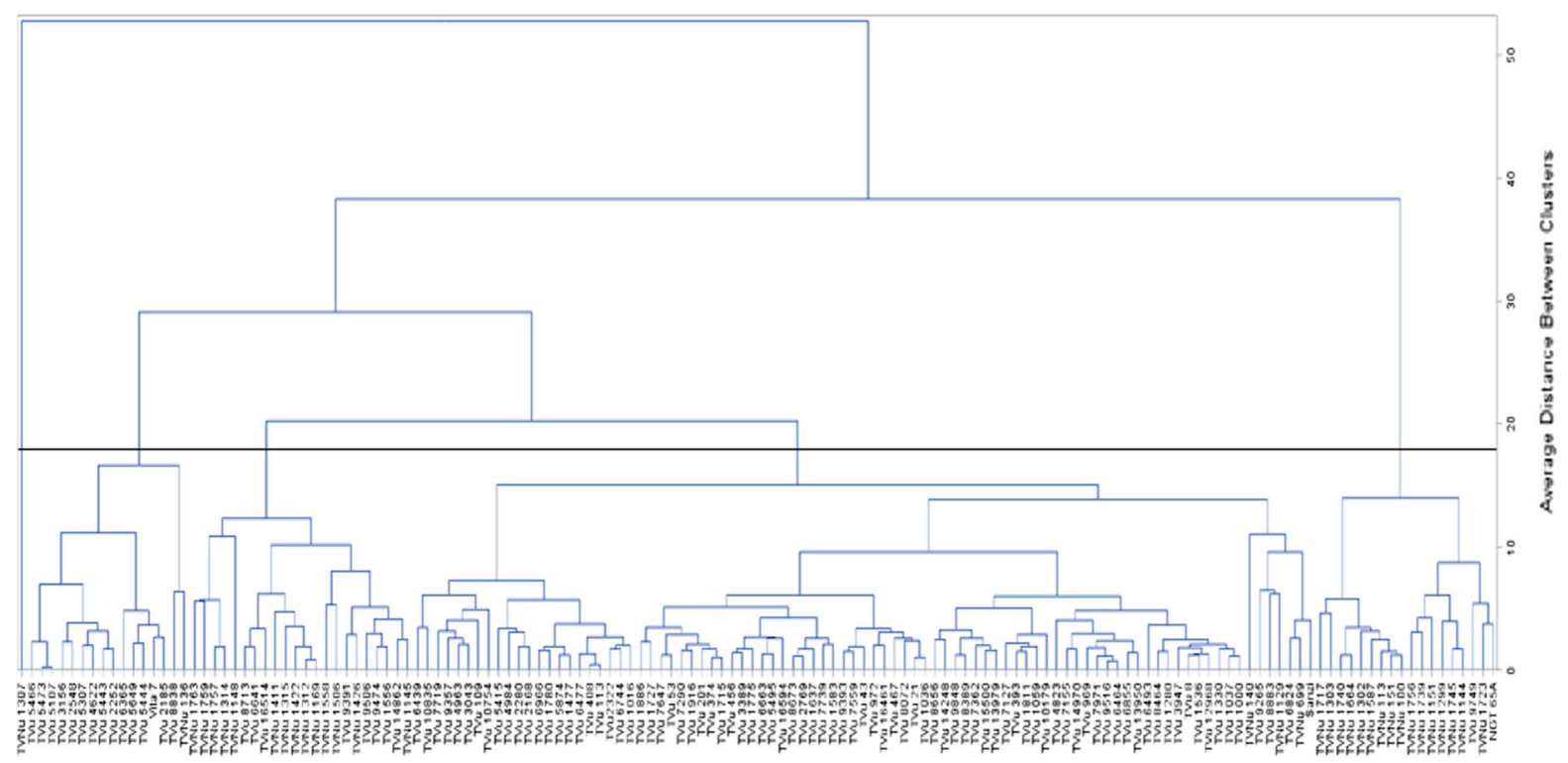

Fig. 1 Dendrogram of 146 cowpea lines based on flower bud thrips resistance and yield-related traits under natural thrips infestation at Fasola and Ile-Ife, 2016

and the fifth group was made up of 18 lines. Clusters 2 , 3 and 5 had two sub-clusters each while cluster 4 had four. Cluster 1 had the lowest damage scores, the highest number of pods per plant and number of pods per peduncle. Clusters 2, 3, 4 and 5 had similar damage scores 1 and 2 (Table 4). For damage score 3, clusters 2 and 3 had similar values which were different from those of clusters 4 and 5 which had similar values. Clusters 1 and 5 had high number of pods per plant and a relatively high number of pods per peduncle while clusters 2, 3 and 4 had low values for these traits. Cluster 2 had the highest number of peduncles per plant, clusters 1,3 and 5 had similar number of peduncles per plant even as cluster 4 had the lowest.
Phenotypic and genetic correlation coefficients of thrips damage scores and agronomic traits are presented in Table 5. Damage score 3 had significant positive genetic and phenotypic correlations with scores 1 and 2 but significant negative genetic correlations with number of pods per plant, number of peduncles per plant and number of pods per peduncle.

Under thrips infestation, stepwise-multiple regression identified number of pods per peduncle, number of peduncles per plant and thrips damage score 3 as first-order contributors to yield (Number of pods per plant), accounting for about $64 \%$ of total variation (Fig. 2). Among the traits, number of pods per

Table 4 Mean values of thrips damage scores and three agronomic traits of 146 cowpea lines in 5 clusters

\begin{tabular}{lccccc}
\hline Variable & Cluster 1 $(\mathrm{n}=1)$ & Cluster 2 $(\mathrm{n}=16)$ & Cluster3 $(\mathrm{n}=22)$ & Cluster $4(\mathrm{n}=89)$ & Cluster 5 $(\mathrm{n}=18)$ \\
\hline DS 1 & 2.00 & 2.94 & 3.06 & 2.98 & 2.92 \\
DS 2 & 3.40 & 4.64 & 4.72 & 4.38 & 4.28 \\
DS 3 & 3.92 & 7.98 & 7.21 & 5.47 & 5.57 \\
Pods/Plt & 4.36 & 0.87 & 0.55 & 0.68 & 3.31 \\
Peds/Plt & 14.32 & 16.55 & 13.83 & 10.33 & 13.27 \\
Pods/Ped & 0.30 & 0.05 & 0.03 & 0.07 & 0.25 \\
\hline
\end{tabular}

DS 1 damage score 1, DS 2 damage score 2, DS 3 damage score 3, Pods/Plt number of pods/plant, Peds/Plt number of pods/peduncle, Pods/Ped number of peduncles/plant 
Table 5 Genetic $\left(r_{g}\right)$ and phenotypic $\left(r_{p}\right)$ correlations among traits of 146 cowpea lines evaluated under natural flower bud thrips infestation at Fasola and Ile-Ife, 2016

\begin{tabular}{lllllll}
\hline Trait & DS 1 & DS 2 & DS 3 & Pods/plt & Peds/plt & Pods/ped \\
\hline DS 1 & - & $0.82^{* *}$ & $0.71^{* *}$ & -0.18 & $-0.24^{*}$ & 0.24 \\
DS 2 & $0.73^{* *}$ & - & $0.71^{* *}$ & -0.30 & $-0.39^{* *}$ & 0.37 \\
DS 3 & $0.65^{* *}$ & $0.51^{*}$ & - & $-0.40^{* *}$ & $-0.47^{* *}$ & $-0.56^{* *}$ \\
Pods/plt & $-0.47^{* *}$ & $-0.47^{* *}$ & $-0.37^{* *}$ & - & $0.64^{* *}$ & $0.72^{* *}$ \\
Peds/plt & -0.04 & -0.15 & $-0.47^{* *}$ & 0.15 & - & $0.34^{*}$ \\
Pods/ped & $-0.46^{* *}$ & $-0.49^{* *}$ & $-0.48^{* *}$ & $0.72^{* *}$ & -0.22 & - \\
\hline
\end{tabular}

DS 1 damage score 1, DS 2 damage score 2, DS 3 damage score 3, Pods/plt number of pods per plant, Peds/plt number of peduncles per plant, Pods/ped number of pods per peduncle

Upper diagonal $=$ genotypic correlation coefficients $\left(\mathrm{r}_{\mathrm{g}}\right)$, lower diagonal $=$ phenotypic correlation coefficients. *, **Indicate $\mathrm{r}-\mathrm{value}$ significantly different from zero at $5 \%$ and $1 \%$ level of probability, respectively

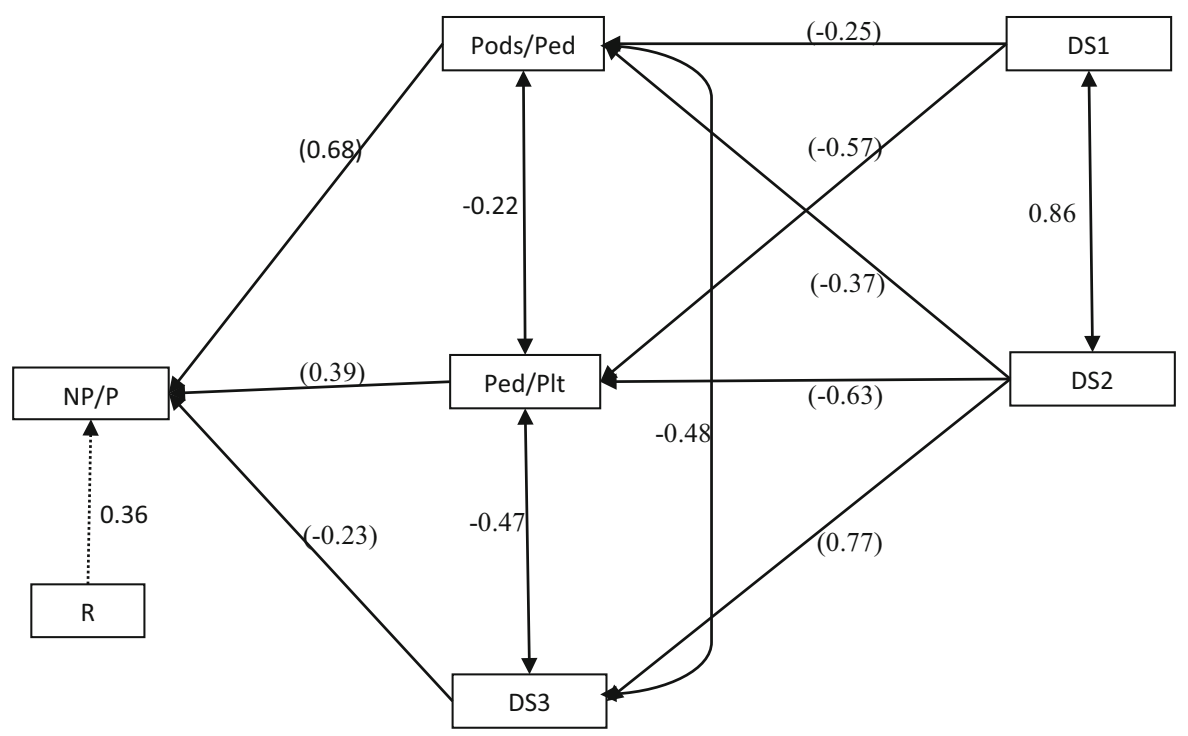

Fig. 2 Path analysis of interrelationships among traits of 146 cowpea lines screened for thrips resistance under natural infestation at Fasola and Ile-Ife, 2016. Values in parenthesis are direct effects and other values are correlation co-efficients.

peduncle had the highest direct effect $(0.68)$ on yield, with the direct effects of the two other traits being relatively much lower. Among the three traits, only damage score 3 had a negative direct effect on yield. Damage scores 2 and 3 were second-order variables.

\section{Discussion}

Genetic variability is the basic raw material for crop improvement (Poehlman and Sleper 1995). This study
$R$ residual effects, $N P / P$ number of pods per plant, Pods/ped number of pods per peduncle, $P e d s /$ plt number of peduncles per plant, $D S 3$ damage score $3, D S 2$ damage score 2

indicated the availability of a broad genetic variability for resistance to flower bud thrips among the 146 test lines, thereby establishing the feasibility for genetic enhancement of the trait using existing cowpea germplasm. Cowpea lines possessing resistance include TVu 6824, a cultivated line, and TVNu 1307, which is a wild line of the dekindtiana subspecies. These lines would serve as invaluable sources of resistance alleles for the genetic improvement of cowpea for resistance to flower bud thrips. The significant genotype $\times$ environment interaction for all 
traits except damage score 1 and number of pods per peduncle revealed the instability of flower thrips resistance among the lines across environments. Agbahoungba et al. (2017) reported significant genotype $\times$ environment interaction effects for thrips resistance indicator traits in a set of cowpea lines evaluated under natural infestation across three locations in Uganda. Similarly, Doumbia et al. (2019) reported instability in thrips resistance among a different set of cowpea lines evaluated in Mali. The significant environment and genotype $\mathrm{x}$ environment interaction effects for damage scores 2 and 3 along with measured agronomic traits of the test lines confirmed the importance of multilocational screening of genotypes in resistance breeding (Van Ginkel and Rajaram 1993).

The relationships among the test lines as explained by the dendrogram further established the existence of a broad variability among the test lines. This variability is useful to cowpea breeders for developing thrips resistant varieties as hybridization between genetically distant parents often results in desirable progenies due to heterozygosity (Falconer 1981). The low genetic distance observed between TVu 6824 and Sanzi, the resistant check, suggested that the resistance genes in the two lines are similar unlike the high genetic distance between TVNu 1307, a resistant wild cowpea relative, and Sanzi signifying that their genes for resistance are different. These resistance genes could be stacked in elite but susceptible cowpea varieties to provide durable resistance.

Breeders and geneticists require precise information on relationships among traits to facilitate gains from selection. A core objective of the present study was to identify suitable traits for effective selection for thrips resistance in cowpea. Information from correlation analysis is useful for breeders to formulate effective simultaneous selection strategies (Ekvised et al. 2006). However, correlation coefficient is only an indication of the direction (negative or positive) and level (high or low) of bivariate relationships. It does not explain the cause and effect of the relationship. Sequential path analysis provides information on cause and effect relationships among traits by identifying traits with significant effects on the dependent variable, and arranging them as first, second or thirdorder variables in descending order of their relative importance in explaining the total variation in the dependent variable. While traits classified in the first order are considered traits of value, second-order traits are regarded as traits of potential importance (BaduApraku et al. 2014). The negative correlation observed between thrips damage score 3 and number of peduncles per plant under thrips infestation, confirmed reduction or non-elongation of peduncles as a symptom of thrips attack on cowpea. The negative correlation between number of pods per plant and the three damage scores established the negative impact of flower thrips attack on cowpea yield. Damage score 3, despite having the lowest correlation co-efficient with yield relative to the two other scores, was the only damage score grouped in the first order in the analysis. This revealed the defects of selecting for thrips resistance on the basis of correlation analysis alone. Genetic correlation coefficient provides a measure of genetic linkage between two traits. The significant negative genetic correlation between damage scores on one hand and yield parameters on the other indicated that resistance genes were not linked with those that moderate yield. However, the presence of the resistance genes might be necessary for formation of pods under thrips infestation.

Evaluation of plant reactions to insect pest infestation is usually based on multiple evaluations in time and location; that is, environments. It is important to determine which assessment time is most appropriate and gives the most accurate data for plant breeders to eliminate inconsequential assessment times. From the results of this study, damage score 3 had the largest direct effect on yield. This implied that earlier damage scores, particularly damage score 1 , is not as important, indicating that early assessment may not be appropriate because, as observed by Agbahoungba et al. (2017), initial number of infesting thrips will be few and migrating thrips population would need more time to establish on the test plants. In addition to damage score 3 , path analysis also identified number of pods per peduncles and number of peduncles per plant as first-order traits contributing to yield (number of pods per plant). One of the characteristic symptoms of thrips damage in cowpea is a reduction in the number of elongated peduncles (Jackai and Singh 1988). Since thrips cause flower buds to drop, no pods are formed. Hence, the peduncles remain stunted as there are no pods to support. This indicated that for selection and breeding, these traits would be useful as selection criteria for thrips resistance in cowpea. Damage score 2 had negative indirect effects on yield 
through all of the three first-order traits, thereby also identifying it as trait of potential importance.

\section{Conclusion}

The genetic variability observed among the lines evaluated in this study offers the potential for genetic improvement of cowpea for thrips resistance. Lines $\mathrm{TVu} 6824$ and TVNu 1307 were found as possessing high resistance to flower bud thrips. Damage score 3, number of peduncles per plant and number of pods per peduncle are useful traits as selection criteria in breeding for thrips resistance in cowpea.

Acknowledgements This study was supported by the Bill and Melinda Gates Foundation. The authors are grateful to Messrs. Ojo J.F. and Alabi A. of IITA Cowpea Breeding Unit for technical support. The authors also acknowledge the immense contributions of staff members of Obafemi Awolowo University Teaching and Research Farm towards the successful execution of this study at Ile-Ife.

Author's contribution JOT conceived the study, executed it and drafted the manuscript. CAF conceived the study, supervised it and reviewed the manuscript. OB conceived and supervised the study. MABF conceived the study, supervised it and reviewed the manuscript. All authors agreed to the final version of the manuscript.

Funding This study benefitted from the funding support of Bill and Melinda Gates Foundation under the Tropical Legumes III project.

Data availability The datasets generated during the present study are available from the corresponding author on formal request.

\section{Declarations}

Conflict of interest The authors declare no conflict of interest.

Consent to participate All authors agreed to be a part of the study.

Consent for publication All authors agreed that the manuscript be submitted to Euphytica.

Open Access This article is licensed under a Creative Commons Attribution 4.0 International License, which permits use, sharing, adaptation, distribution and reproduction in any medium or format, as long as you give appropriate credit to the original author(s) and the source, provide a link to the Creative Commons licence, and indicate if changes were made. The images or other third party material in this article are included in the article's Creative Commons licence, unless indicated otherwise in a credit line to the material. If material is not included in the article's Creative Commons licence and your intended use is not permitted by statutory regulation or exceeds the permitted use, you will need to obtain permission directly from the copyright holder. To view a copy of this licence, visit http://creativecommons.org/licenses/by/4.0/.

\section{References}

Agbahoungba S, Karungi J, Odong TL, Badji A, Sadik K, Rubaihayo PR (2017) Stability and extent of resistance of cowpea lines to flower bud thrips in Uganda. Afr Crop Sci J 25(1): $1-24$

Badu-Apraku B, Akinwale RO, Oyekunle M (2014) Efficiency of secondary traits in selecting for improved grain yield in extra-early maize under Striga-infested and Striga-free environments. Maydica 55:261-274

Boukar O, Fatokun CA, Huynh B, Roberts PA, Close TJ (2016) Genomic tools in cowpea breeding programs: status and perspectives. Front Plant Sci 7:757. https://doi.org/10. 3389/fpls.2016.00757

Doumbia IZ, Boukar O, Tamo M, Tignegre J, Fatokun CA, Togola A, Tongoona P, Ayertey JN (2019) Evaluation of cowpea accessions for resistance to flower bud thrips (Megalurothrips sjostedti) in Mali. J Genet Genom Plant Breed 3(2):15-30

Ekvised S, Jogby S, Akkasaeng C, Keerati-Kasikorn M, Kesmala T, Buddhasimma I, Patanothai A (2006) Heritability and correlation of thrips resistance and agronomic traits in peanut. Asian J Plant Sci 5(6):923-937

Falconer DS (1981) Introduction to quantitative genetics, 2nd edn. Longman, London, p 340

Fatokun CA (2002) Breeding cowpea for resistance to insect pests: attempted crosses between cowpea and Vigna vexillata. In: Fatokun CA, Tarawali SA, Singh BB, Kormawa PM, Tamo M (eds) Challenges and opportunities for enhancing sustainable cowpea production. Proceedings of the World Cowpea conference III held at the International Institute of Tropical Agriculture (IITA), Ibadan, Nigeria, 4-8th Sept, 2002, pp 52-60

Haruna IM, Usman A (2013) Agronomic efficiency of cowpea varieties (Vigna unguiculata (L.) Walp.) under varying phosphorus rates in Lafia, Nasarawa state, Nigeria. Asian J Crop Sci 5:209-215

Jackai LEN, Daoust RA (1986) Insect pests of cowpeas. Annu Rev Entomol 31:95-119

Jackai LEN, Singh SR (1988) Screening techniques for host plant resistance to insect pests of cowpea. Trop Grain Legume Bull 35:2-18

Kormawa PM, Chianu JN, Manyong VM (2002) Cowpea demand and supply patterns in West Africa: the case of Nigeria. In: Fatokun CA, Tarawali SA, Singh BB, Kormawa PM, Tamo M (eds) Challenges and opportunities for enhancing sustainable cowpea production. Proceedings of the World Cowpea conference III held at the International Institute of Tropical Agriculture (IITA), Ibadan, Nigeria, 4-8th Sept, 2002, pp 52-60 
Mohammadi SA, Prasanna BM, Singh NN (2003) Sequential path model for determining interrelationships among grain yield and related characters in maize. Crop Sci 43:1690-1697. https://doi.org/10.2135/cropsci2003.1690

Morse JG, Hoddle MS (2006) Invasion biology of thrips. Annu Rev Entomol 51:67-89

Nault LR (1997) Arthropod transmission of plant viruses: a new synthesis. Ann Entomol Soc Am 90:521-541

Okonya JS, Maass BL (2014) Potential of cowpea variety mixtures to increase yield stability in subsistence agriculture: preliminary results. Int J Agron. https://doi.org/10. $1155 / 2014 / 515629$

Oladejo AS (2015) Genetic analysis of resistance of some cowpea (Vigna unguiculata [L.] Walp.) lines to thrips (Megalurothrips sjostedti Trybom). A Ph.D. Thesis, Department of Crop Production and Protection, Obafemi Awolowo University, Ile-Ife, Nigeria

Oladejo AS, Boukar O, Fatokun CA, Obisesan IO (2017) Genetic analysis of thrips resistance in cowpea (Vigna unguiculata (L.) Walp.). Euphytica 213:216

Omo-Ikerodah EE, Fatokun CA, Fawole I (2009) Genetic analysis of resistance to flower bud thrips (Megalurothrips sjostedti) in cowpea (Vigna unguiculata (L.) Walp.). Euphytica 165:143-146

Poehlman JM, Sleper DA (1995) Breeding field crops. Iowa State University Press Ames, Iowa

Raj KJ, Sanghamitra N (2010) Gene pyramiding-A broad spectrum technique for developing durable stress resistance in crops. Biotechnol Mol Biol Rev 5(3):51-60

SAS Institute (2001) Statistical analysis system (SAS) user's guide. SAS Institute, Cary

Singh SR, Allen DJ (1980) Pests, diseases, resistance and protection in cowpeas. In: Summerfield RJ, Bunting AH (eds)
Advances in legume science. Royal Botanical Gardens, Kew, pp 419-443

Singh BB, Chamblis OL, Sharma B (1997) Recent advances in cowpea breeding. In: Singh BB, Mohan Raj DR, Dashiell KE, Jackai LEN (eds) Advances in cowpea research. Copublication of International Institute of Tropical Agriculture (IITA) and Japan International Research Centre for Agricultural Sciences (JIRCAS), IITA, Ibadan, pp 30-49

Singh BB, Chamblis OL, Sharma B (2002) Recent advance in cowpea breeding. In: Fatokun CA, Tarawali SA, Singh BB, Kormawa PM, Tamo M (eds) Challenges and opportunities for enhancing sustainable cowpea production. Proceedings of the World Cowpea conference III held at the International Institute of Tropical Agriculture (IITA), Ibadan, Nigeria, 4-8 Sept, 2002, pp 182-189

Terao T, Watanabe I, Matsunaga R, Hakoyama S, Singh BB (1997) Agro-physiological constraints in intercropped cowpea: an analysis. In: Singh BB, Mohan Raj DR, Dashiell KE, Jackai LEN (eds) Advances in cowpea research. IITA/JIRCAS Co-Publication, IITA, Ibadan, pp 129-140

Van Ginkel M, Rajaram S (1993) Breeding for durable resistance to diseases in wheat: an international perspective. In: Jacobs T, Parlevliet JE (eds) Durability of disease resistance. Current plant science and biotechnology in agriculture, vol 18. Springer, Dordrecht. https://doi.org/10. 1007/978-94-011-2004-3_28

Ward JH (1963) Hierarchical groupings to optimize an objective function. J Am Stat Assoc 58:236-244

Publisher's Note Springer Nature remains neutral with regard to jurisdictional claims in published maps and institutional affiliations. 